\title{
Kezdeti tapasztalataink a petefészekszövet-fagyasztás bevezetésével
}

\author{
Fancsovits Péter dr. ${ }^{1}$ - Urbancsek János dr. ${ }^{1}$ - Fónyad László dr. ${ }^{2}$ \\ Sebestyén Anna dr. ${ }^{2}$ - †Csorba Gézáné ${ }^{2}$ - Lehner Ádám ${ }^{1}$ - Kaszás Zita ${ }^{1}$ \\ Rigó János jr. dr. ${ }^{1}$. Bokor Attila dr. ${ }^{1}$
}

\begin{abstract}
Semmelweis Egyetem, Általános Orvostudományi Kar, ${ }^{1}$ I. Szülészeti és Nőgyógyászati Klinika,
\end{abstract} ${ }^{2}$ I. Patológiai és Kísérleti Rákkutató Intézet, Budapest

\begin{abstract}
Bevezetés: A nőbetegek onkológiai kezelése a petefészek-múködés károsodását okozhatja. Ennek megelőzésére lehetôség van a petefészekszövet mélyfagyasztására, hosszú távú tárolására, majd a petefészek-múködést károsító beavatkozások után a szövetminták visszaültetésére. Célkitüzés: Jelen tanulmányban a szerzók azt vizsgálták, hogy a petefészekszövet-fagyasztás módszerei mennyiben befolyásolják a felolvasztott szövetminták életképességét. Módszer: A munka során 10 kutatási célra felajánlott szövetminta fagyasztását-felolvasztását végezték el, majd a szövetminták túlélését vizsgálták. Szövettani vizsgálatokkal hasonlították össze a friss és a fagyasztott-felolvasztott mintákban lévő tüszők állapotát, illetve meghatározták hormontermelésüket. Eredmények: Szövettani vizsgálatokkal igazolták, hogy a fagyasztott-felolvasztott mintákban az életképesnek túnő tüszők száma 23\%-kal csökkent, de még a szövettenyésztést követően is megfigyeltek életképes tüszőket. A felolvasztott szövetminták maximális ösztradioltermelése 908 pg/ $\mathrm{ml}$ volt, és a hormontermelés mértéke a friss mintákéhoz hasonló értékeket mutatott. A felolvasztott szövetek progeszterontermelésének maximuma $1,95 \mathrm{ng} / \mathrm{ml}$ volt, amely elmaradt a friss szövetminták hormonértékeitől. Következtetések: A szerzők által alkalmazott petefészekszövet-fagyasztási módszerrel biztosítható a tüszők fagyasztás-felolvasztás utáni túlélése, így intézetükben megkezdték a módszer kísérleti klinikai alkalmazását daganatos betegek termékenységének megőrzése céljából. Orv. Hetil., 2016, 157(49), 1947-1954.
\end{abstract}

Kulcsszavak: petefészekszövet-fagyasztás, petefészek-transzplantáció, kemoterápia, meddőség

\section{First attempts in the introduction of cryopreservation of ovarian tissues}

Introduction: The oncological treatment may damage ovarian function. To prevent this, it is possible to cryopreserve the ovarian tissue, and to keep the samples for long-term storage. The frozen-thawed tissue could be retransplanted after chemo- or radiotherapy. Aim: The aim of our study was to examine the effect of cryopreservation on the viability of ovarian tissue. Method: We analyzed the survival of frozen-thawed donated ovarian tissues. The quality of the follicles and hormone production in fresh and frozen-thawed samples were compared. Results: Histological analysis showed that the number of viable follicles was reduced by $23 \%$ in the frozen-thawed samples. However, viable follicles still presented in post thawing ovarian tissues. Maximal estradiol production in frozen-thawed tissues was 908 $\mathrm{pg} / \mathrm{ml}$ and hormone production was similar to the control tissues. The maximal progesterone production was 1.95 $\mathrm{ng} / \mathrm{ml}$ post thawing, but these values were lower than the progesterone production of fresh tissues. Conclusions: The method of ovarian cryopreservation used in our laboratory was able preserve the viability of follicles in frozen-thawed ovarian tissues.

Keywords: ovarian tissue cryopreservation, ovarian tissue transplantation, chemotherapy, infertility

Fancsovits, P., Urbancsek, J., Fónyad, L., Sebestyén, A., †Csorba, G., Lebner, Á., Kaszás, Z., Rigó, J. jr., Bokor, A. [First attempts in the introduction of cryopreservation of ovarian tissues]. Orv. Hetil., 2016, 157(49), 1947-1954.

(Beérkezett: 2016. július 28.; elfogadva: 2016. október 2.) 


\section{Rövidítések}

DMEM = Dulbecco's Modified Eagle Medium; DMSO = dimethyl sulfoxide; DPBS $=$ Dulbecco's phosphate-buffered saline; ELISA = enzyme-linked immunosorbent assay; FCS = fetal calf serum; SSS $=$ (synthetic serum substitute) humán szérumalbumin

A daganatos fiatal nőbetegek kemo-, illetve radioterápiája miatt kialakuló korai petefészek-elégtelenség a nemi hormonok termelésének leállásához, amenorrhoeához és meddőséghez vezet. Annak ellenére, hogy a sikeres daganatterápia megmenti a beteg életét, a „mellékhatásként” fellépő petefészek-elégtelenség az életminőséget rontja és sok esetben a gyermekvállalást is lehetetlenné teszi [1].

A kemoterápia alkalmazásakor az adott szer által előidézett károsító hatás mértékét nem lehet előre megjósolni. A legsúlyosabb ivarsejt-károsodást az alkilálószerek (például: cyclophosphamid, clorambucil) okozzák, azonban az antimetabolitok (methotrexat, 5-FU) szintén rendelkeznek gonadotoxikus hatással [2].

Az emberi gonádszövetek és ivarsejtek rendkívül érzékenyek az ionizáló sugárzással szemben, ezért annak hatása gyakran visszafordíthatatlan. Ezen túlmenően a sugárterápia során a méh izomzatának károsodása is létrejöhet. A terhességi szövődmények száma (vetélés, koraszülés, alacsony születési súly) bizonyítottan magasabb azoknál a betegeknél, akik korábban sugárkezelésben részesültek [1].

A daganatos betegségek kezelése során fellépő petefészek-károsító hatások kivédésének egyik lehetséges útja a petefészekszövet-fagyasztás. A módszer lényege, hogy a kemoterápia vagy sugárkezelés előtt az egyik petefészket vagy annak egy részét mütéti úton eltávolítják a szervezetből, és az így nyert szövetmintákat alacsony hőmérsékleten tárolják úgy, hogy a szövetben lévő éretlen tüszők megőrzik életképességüket.

Állatkísérletek során először Smith és Parkes számoltak be patkánypetefészek sikeres fagyasztásáról 1951-ben [3]. Az első, élő utódot eredményező petefészekszövetátültetésre egéren 1961-ben került sor [4]. A módszer házi juhon történő eredményes alkalmazásáról 1994ben Gosden és mtsai számoltak be [5]. Igazolták, hogy házi juhok fagyasztott petefészekszövete a mélyfagyasztás során képes megőrizni életképességét, és a felolvasztást, valamint visszaültetést követően hormontermelést és tüszőérést is kimutattak a szövetekben. Egészséges utódok születéséról szintén beszámoltak.

Humán petefészekszövet fagyasztásáról Hovatta és mtsai számoltak be először 1996-ban [6], és igazolták, hogy az emberi petefészekszövet mélyfagyasztása, a korábbi állatkísérletek eredményeihez hasonlóan, megvalósítható. Rámutattak arra, hogy a petefészekszövet-fagyasztás kiváló lehetőséget biztosíthat a petefészekben fejlődő petesejtek hosszú távú megőrzésére.
Mindez előrevetítette annak a lehetőségét, hogy a petefészekszövet-fagyasztást és -transzplantációt felhasználjuk daganatos betegségben szenvedő nók termékenységének megőrzésére, illetve a hormontermelés visszaállítására. A módszer alkalmazásával először Donnez és mtsai 2004-ben számoltak be sikeres kezelésről, és egészséges újszülött világrajövetelérôl [7]. Az azóta eltelt több mint 10 évben egyre több intézetben végeznek petefészekszövet-fagyasztással kiegészített autológ transzplantációt. Világszerte összesen 60, így fogant gyermek születéséről számoltak be tudományos közleményekben $[8,9]$.

Az eddigi sikeres kezelések során a petefészekszövet fagyasztását programozott lassú fagyasztással, a Gosden és mtsai által [5] kidolgozott módszerrel végezték [10]. Ugyanakkor lehetőség van a szövetminták vitrifikációjára is, ami egy ultragyors (akár $30000{ }^{\circ} \mathrm{C} /$ perc) hútéssel valósul meg. A módszer hatékonyan alkalmazható petesejtek és korai fejlődési stádiumú embriók mélyfagyasztására, azonban petefészekszövet-mélyfagyasztás esetében még nem sikerült egyértelmúen igazolni a vitrifikáció előnyeit a hagyományos lassú fagyasztással szemben [11].

Jelen tanulmányunkban azt vizsgáljuk, hogy a petefészekszövet-fagyasztás során általunk alkalmazott módszerek mennyiben befolyásolják a petefészekszövet-minták fagyasztás és felolvasztás utáni életképességét. Vizsgálataink célja, hogy intézetünkben a petefészekszövet-minták fagyasztásának laboratóriumi módszereit bevezessük a rutin klinikai gyakorlatba.

\section{Betegek és módszer}

Vizsgálatainkhoz a Semmelweis Egyetem I. Szülészeti és Nőgyógyászati Klinikáján laparoszkópos petefészekműtét során eltávolított és kutatási célra felajánlott petefészekszövet-mintákat használtunk fel. A kutatómunkát az Egészségügyi Tudományos Tanács Humán Reprodukciós Bizottsága által kiállított szakhatósági állásfoglalás (20700-4/2012/EHR), Budapest Főváros Kormányhivatala által kiállított V-R-021/12547-4/2012. számú határozatában foglalt kutatási engedély, valamint a részt vevő betegek által, szóbeli és írásbeli tájékoztatásukat követően adott írásbeli beleegyező nyilatkozat birtokában végeztük.

A vizsgálatba bevont 10 betegtől egyenként körülbelül $10 \times 10 \mathrm{~mm}$-es petefészekszövet-mintát nyertünk kutatási célra. Olyan betegeknél történt mintavétel, akiknél nőgyógyászati betegségük miatt petefészekmütét történt, és hozzájárultak ahhoz, hogy a mútét során petefészkükből egy kisebb szövetdarabot eltávolítsunk, és kutatási célra felhasználjunk.

\section{A petefészekszöpet-minták feldolgozása}

A petefészekszövet-minták feldolgozását és fagyasztását a Gosden és mtsai [5] által leírt és később módosított pro- 

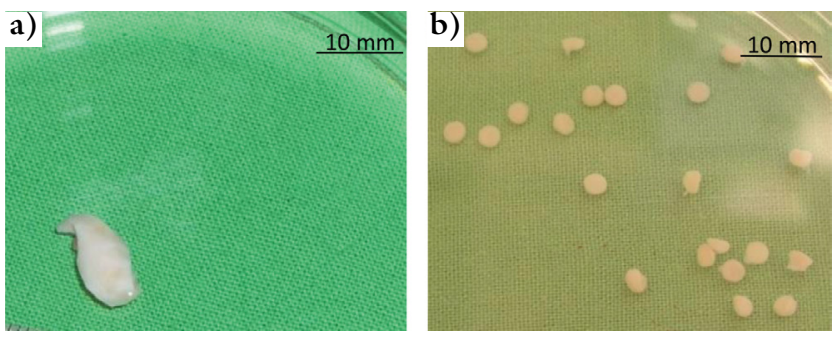

1. ábra

Kutatási célra felajánlott petefészekszövet-minta feldolgozása a) Feldolgozás előtti szövetminta. b) Biopsziás túvel azonos méretü, $3 \mathrm{~mm}$ átmérőjü darabokra vágott petefészek-kéregállomány a fagyasztáshoz vagy túlélési vizsgálatokhoz előkészítve

tokoll [12, 13] alapján végeztük. A szövetmintákat valamennyi laboratóriumi folyamat során steril körülmények között kezeltük. A szöveteket a mintavételt követően szoba-hőmérsékletű Custadiol transzplantációs oldatba (Dr. Franz Köhler Chemie GmbH, Bensheim, Németország) helyeztük, és az Asszisztált Reprodukciós Osztály Embriológiai Laboratóriumába szállítottuk, ahol a feldolgozásig és fagyasztásig $+4{ }^{\circ} \mathrm{C}$-on tároltuk. A szövetminták feldolgozását $+4{ }^{\circ} \mathrm{C}$-ra hütött munkafelületen, transzplantációs oldatban végeztük. A feldolgozás során a petefészek velőállományát eltávolítottuk és a kéregállományból biopsziás tűvel $3 \mathrm{~mm}$ átmérőjű szövetdarabokat készítettünk (1. ábra). Az így nyert szövetdarabok egy részét lefagyasztottuk, másik részét pedig fagyasztás nélküli kontrollcsoportnak használtuk.

\section{A petefészelsszöpet-minták fagyasztása, tárolása, felolvasztása}

A fagyasztásra kerülő szövetmintákat $+4{ }^{\circ} \mathrm{C}$-ra hütött, DMSO-val (Sigma-Aldrich, Steinheim, Németország) és humán szérumalbuminnal (SSS, Irvine, Santa Ana, CA, Amerikai Egyesült Államok) kiegészített Leibovitz's L-15 fagyasztóoldatba (Gibco Life Technologies, Paisley, Nagy-Britannia) helyeztük. A fagyasztóoldatban 40 percig $2{ }^{\circ} \mathrm{C}$-on inkubáltuk, majd programozható fagyasztókészülékkel (Planer Sunbury-On-Thames; NagyBritannia) hűtöttük le. A hűtés első szakaszában $2^{\circ} \mathrm{C} /$ perc hütési sebességet alkalmaztunk, majd $-6^{\circ} \mathrm{C}$-on váltottuk ki a jégkristályképződést (manual seeding) a mintákban. Ezt követően $-40{ }^{\circ} \mathrm{C}$-os hőmérsékletig $0,3{ }^{\circ} \mathrm{C} /$ perc, majd $-140^{\circ} \mathrm{C}$-ig $10^{\circ} \mathrm{C} /$ perc sebességgel történt a hütés. A lefagyasztott mintákat legalább egy hétig folyékony nitrogénben, $-196{ }^{\circ} \mathrm{C}$-on tároltuk.

A felolvasztás során a folyékony nitrogénból kiemelt mintákat 30 másodpercig szobahőmérsékleten tartottuk, majd felolvadásig $37{ }^{\circ} \mathrm{C}$-os vízfürdőbe helyeztük. Ezt követően 0,75 M-tól 0,125 M-ig folyamatosan csökkenő szacharózmennyiséget és $10 \%$ SSS-t tartalmazó Dulbecco's PBS-ből (DPBS, Lonza, Verviers, Belgium) készített szobahőmérsékletú felolvasztó oldatsorba helyeztük a szövetmintát. Az utolsó felolvasztóoldatból GMOPS $^{+}$szövettenyésztő tápoldatba (Vitrolife, Göteborg, Svédország) kerültek a minták felhasználásig.

\section{Túlélési vizsgálatok}

A fagyasztott-felolvasztott minták, valamint a fagyasztás nélküli kontrollminták életképességét többféle módszerrel is vizsgáltuk.

A hagyományos szövettani vizsgálatok során mind a friss, mind a fagyasztott-felolvasztott mintákat fixáltuk, majd paraffinba ágyaztuk be. Ugyanígy fixálásra és beágyazásra kerültek a 21 napos szövettenyésztést követően megmaradt petefészekszövet-minták is. Az összehasonlító vizsgálatokra összesen 40 minta állt rendelkezésünkre. A paraffinos blokkokból 5 mikrométeres metszeteket készítettünk, amiket hematoxilin-eozin festés után digitalizáltunk (Pannoramic Scan, 3DHISTECH, Budapest). A digitális metszeteket Pannoramic Viewer szoftverrel (3DHISTECH, Budapest) jelenítettük meg, és az összes fellelhető folliculusról morfológiai értékelést készítettünk. A tüszők értékeléséhez a Zhou és $m$ tsai [14] által leírt sémát használtuk. Az elvégzett morfológiai vizsgálat alapján minden tüszőt besoroltunk a 2. ábrán feltüntetett csoportok (a) normális tüsző; b) minimális elváltozást mutató tüsző, $c$ ) nekrotizált tüsző) valamelyikébe.

A friss, illetve felolvasztott szövetekben lévő tüszők életképességét vitális festéssel is megvizsgáltuk. A vizsgálatra szánt szövetmintákat Collagenase enzimmel (Sigma-Aldrich) homogenizáltuk, majd Neutral Red oldattal (Sigma-Aldrich) festettük. A Neutral Red festéket csak az élő sejtek veszik fel, így az élő tüszők, illetve petesejtek pirosra festődnek, míg az elhalt sejtek nem mutatnak festődést $[15,16]$.

A szövetek hormontermelésének mértékét 21 napos in vitro szövettenyésztés során ellenőriztük. A petefészek kéregállományából biopsziás tûvel készített $3 \mathrm{~mm}$ átmérôjű szövetdarabokat $1 \mathrm{ml}$ DMEM $100 \mathrm{mg}$ glükóz (Sigma-Aldrich) szövettenyésztő tápoldatba explantáltuk, amelyet 10\% FCS-el (Hyclone, Logan, Amerikai Egyesült Államok) és $160 \mu \mathrm{g} / \mathrm{ml}$ Gentamycinnel (Sandoz Hungary, Budapest) egészítettünk ki. A szövetmintákat 24 vájatú szövettenyésztő edényben, $37^{\circ} \mathrm{C}$-on, $5 \%$-os $\mathrm{CO}_{2}$-koncentráció mellett inkubáltuk. A szövettenyésztő tápoldat frissítése során a tenyésztés 3., 7., 14. és 21 . napján $500 \mu \mathrm{l}$ oldatot szívtunk le, amelyet friss tápoldattal pótoltunk. Az így eltávolított $500 \mu \mathrm{l} 3,7$, 14, illetve 21 napos médiumot fagyasztva $\left(-20{ }^{\circ} \mathrm{C}\right.$-on $)$ tároltuk a hormonmeghatározásig.

A tenyésztésre használt tápoldatok ösztradiol- és progeszterontartalmát ELISA-módszerrel, Immulite 1000 készülékkel (DPC Cirrus Inc., Los Angeles, Amerikai Egyesült Államok) határoztuk meg. A 21 napos szövettenyésztést követően a megmaradt szövetmintát a korábban már leírt módon fixáltuk és hagyományos szövettani vizsgálatot végeztünk.

A fenti vizsgálatokat mind a fagyasztott-felolvasztott, mind pedig a fagyasztás nélküli kontrollmintákon elvégeztük. A fagyasztott minták vizsgálatának eredményeit a kontrollcsoportéval összehasonlítva következtettünk az 

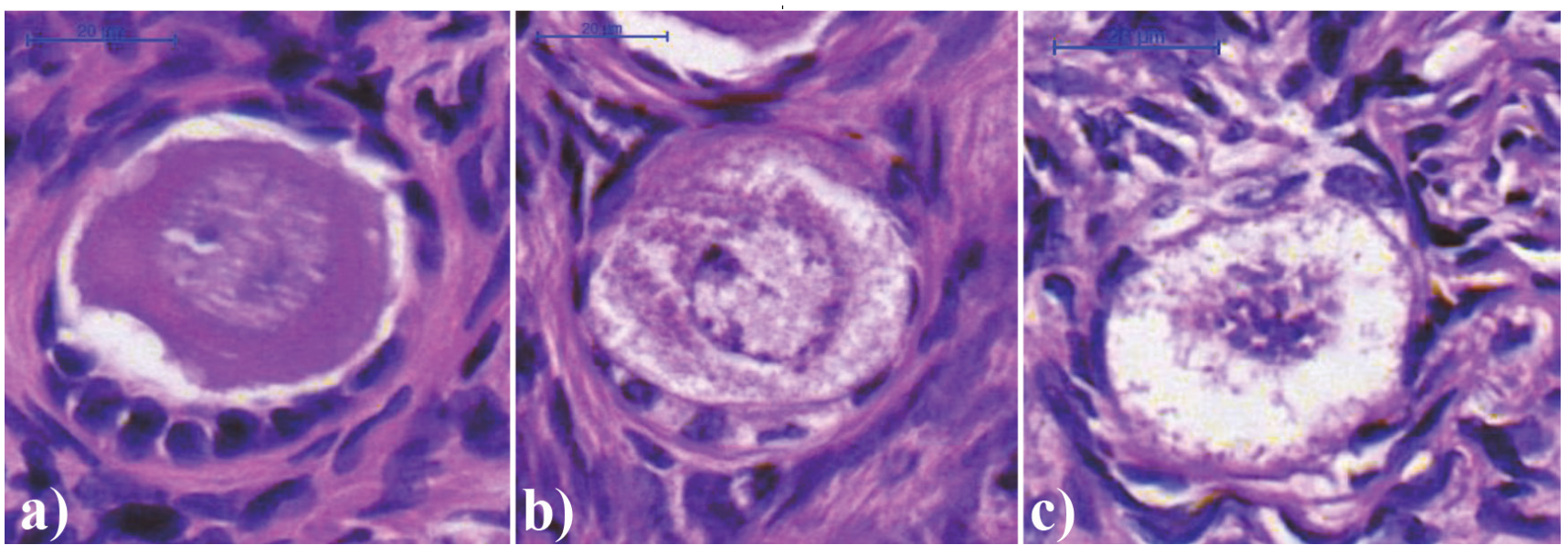

2. ábra

Friss, valamint fagyasztott-felolvasztott petefészekszövet-mintákban található tüszók életképességének megítélése morfológiai jellemzőik alapján. a) Morfológiailag szabályos tüsző, megtartott sejtmag és citoplazma, szabályos fulliculussejtek körkörösen, megtartott zona pellucida. b) Deformált petesejt, inkomplett zona pellucida, szabálytalan folliculussejtek. c) Nekrotizált tüsző, széteső petesejt és folliculussejtek

általunk alkalmazott fagyasztási módszerek hatékonyságára és a felolvasztott minták életképességére. A vizsgálatok elvégzése után a kutatási célra gyüjtött szövetminták megsemmisítésre kerültek.

A kutatási eredményekról készült beszámoló alapján az ÁNTSZ IF-IF-7221-14/2015 számú határozatában engedélyezte a kutatási terv második szakaszának megkezdését, amelyben a petefészekszövet-fagyasztás módszerét klinikai alkalmazásban, daganatos betegek petefészekszövet-átültetése és termékenységének megőrzése céljából végezhetjük.

\section{Eredmények}

A kutatási célra felhasznált szövetminták mindegyike olyan betegból származott, ahol petefészekciszta miatt történt laparoszkópos ovariumreszekció. A 10 beteg közül nyolcnál petefészket is érintő endometriosis, egy esetben dermoid tömlö, egy további esetben pedig perzisztáló follicularis ciszta állt a betegség háttérében.

A hagyományos szövettani vizsgálatok során feldolgozott friss kontrollszövetmintákban 153, míg a fagyasztott-felolvasztott mintákban 102 tüszőt figyeltünk meg.

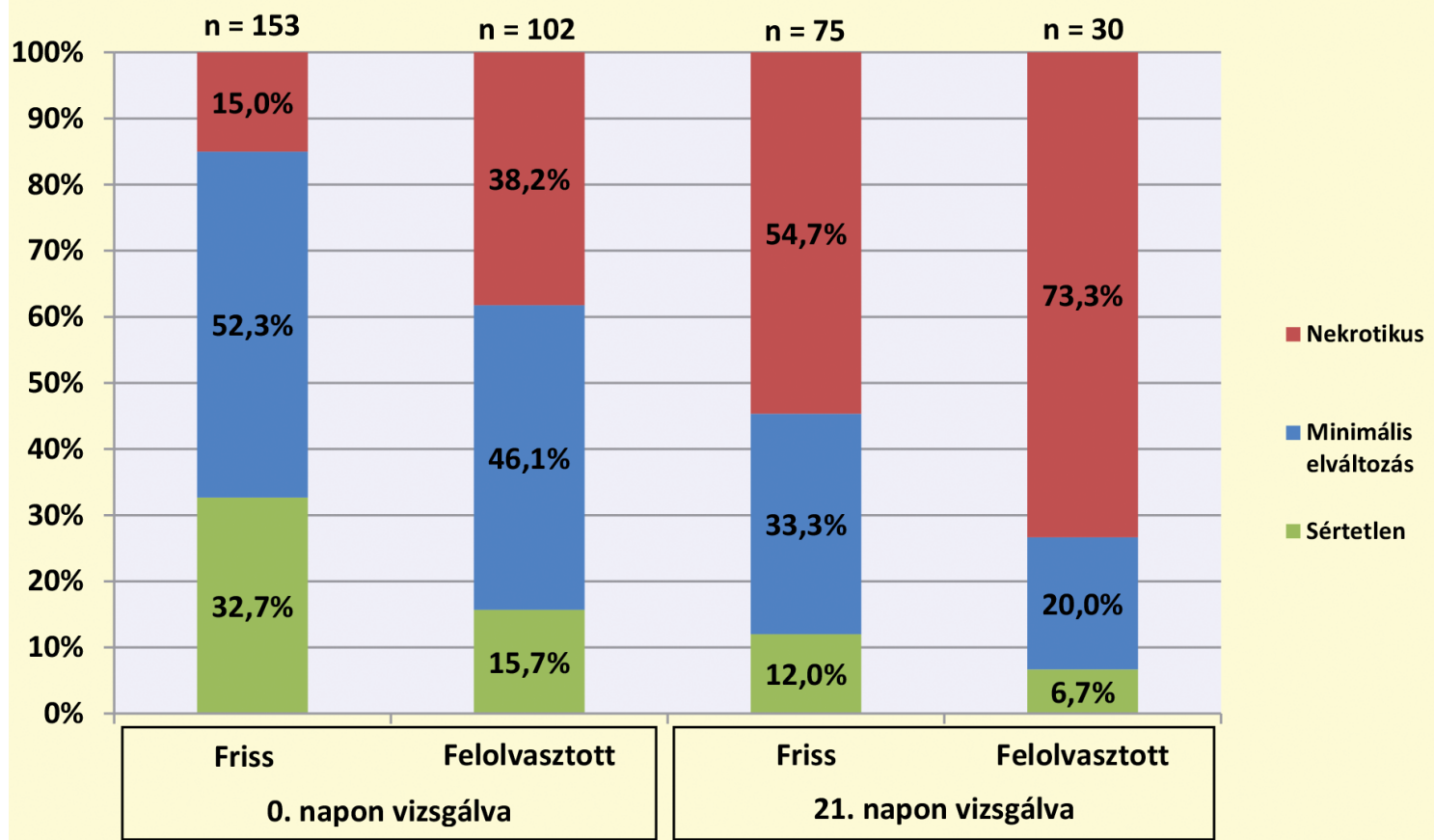

3. ábra

\footnotetext{
Tüszók állapotának vizsgálata friss és fagyasztott-felolvasztott petefészekszövet-mintákon

n = A szövettani vizsgálat során feldolgozott metszetekben azonosított tüszők száma.

0 . nap = Friss minta esetén a mintavétel napja, fagyasztott-felolvasztott minta esetében pedig a felolvasztás napja.

21. nap = A 21 napos szövettenyésztés után végzett vizsgálat
} 

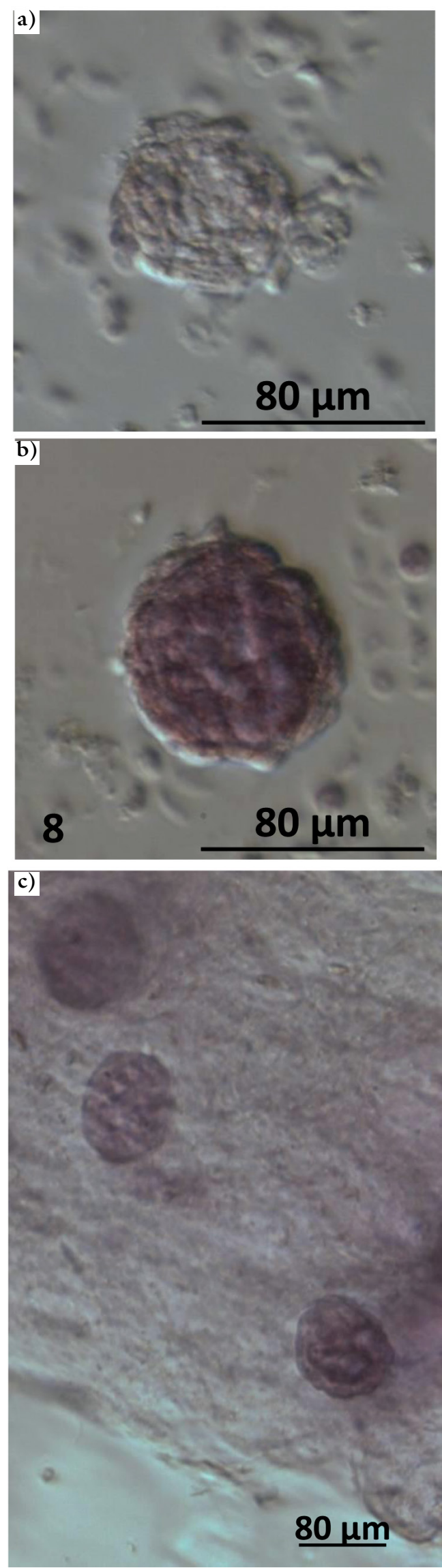

4. ábra Neutral Red módszerrel festődést nem mutató elhalt (a), valamint pirosra festődött élő (b és c) tüszők
A mintánkénti tüszőszám a kontrollcsoportban 0 és 37, míg a fagyasztott-felolvasztott csoportban 0 és 76 között változott. A friss, valamint felolvasztott minták 21 napos szövettenyésztését követően 75 , illetve 80 tüsző vizsgálatát végeztük el. A tüszőket sértetlen, minimális elváltozást mutató, illetve degenerált csoportokba soroltuk (2. ábra), amelyek megoszlását a friss, valamint fagyasztott-felolvasztott szövetekben a 3. ábra mutatja.

A Neutral Red vitális festés során mind a kontrollmintákban, mind pedig a felolvasztott mintákban sikerült kimutatni jól festődő sejteket, illetve tüszőket (4. ábra). Ugyanakkor nem minden esetben lehetett egyértelmúen megállapítani, hogy az enzimes emésztést követően visszamaradt sejtcsomók melyike tartalmaz tüszőt és melyik nem.

A friss, valamint fagyasztott-felolvasztott szövetminták 21 napos tenyésztése során a szövettenyésztő tápoldatban mért ösztradiol- és progeszteronértékeket az 5. és 6 . ábrán tüntettük fel.

A fagyasztás nélküli, friss szövetminták ösztradioltermelése a 3., 7., 14. és 21. napon $467 \pm 437 \mathrm{pg} / \mathrm{ml}$, $765 \pm 534 \mathrm{pg} / \mathrm{ml}, 825 \pm 567 \mathrm{pg} / \mathrm{ml}, 926 \pm 663 \mathrm{pg} / \mathrm{ml}$ volt. A felolvasztott minták esetében pedig $379 \pm 184 \mathrm{pg} /$ $\mathrm{ml}, 664 \pm 342 \mathrm{pg} / \mathrm{ml}, 908 \pm 589 \mathrm{pg} / \mathrm{ml}, 694 \pm 534 \mathrm{pg} /$ ml-es értékeket mértünk. Az egyazon időpontban mért átlagos ösztradiolértékek nem különböztek szignifikánsan a friss és fagyasztott-felolvasztott szövetminták esetében (5. ábra).

A fagyasztás nélküli, friss szövetminták átlagos ösztradioltermelése a tenyésztés 21 . napján érte el maximális értékét $(926 \mathrm{pg} / \mathrm{ml})$, míg a fagyasztott-felolvasztott minták esetében az ösztradioltermelés maximuma a 14. napon jelentkezett $(908 \mathrm{pg} / \mathrm{ml})$. Ezt követően a szöveti ösztradioltermelés intenzitása csökkent, azonban a 21. napon mért érték sem különbözött szignifikánsan a friss szövetminták hormontermelésétől.

A friss szövetminták esetében a 3., 7., 14. és 21. napon $0,64 \pm 0,83 \mathrm{ng} / \mathrm{ml}, 1,29 \pm 1,66 \mathrm{ng} / \mathrm{ml}, 3,39 \pm 3,61 \mathrm{ng} /$ $\mathrm{ml}$, valamint $3,55 \pm 3,09 \mathrm{ng} / \mathrm{ml}-\mathrm{es}$, folyamatosan emelkedő progeszteronértékeket mértünk. A fagyasztott-felolvasztott szövetminták esetében pedig $0,19 \pm 0,14 \mathrm{ng} /$ $\mathrm{ml}, 0,31 \pm 0,21 \mathrm{ng} / \mathrm{ml}, 1,95 \pm 1,70 \mathrm{ng} / \mathrm{ml}$ és $1,71 \pm 2,16 \mathrm{ng} / \mathrm{ml}$ volt a progeszterontermelés a szövettenyésztés során (6. ábra). Bár a progeszterontermelés a friss és felolvasztott szövetminták esetében hasonló görbével ábrázolható, a felolvasztott mintáknál alacsonyabb értékeket mértünk a kontroll- (fagyasztás nélküli) mintákhoz képest. Az eltérés szignifikánsnak bizonyult a 3 . $(p<0,01)$, a 7 . $(p<0,01)$ és a 21 . napon $(p=0,03)$ is. A progeszterontermelés a friss minták esetében a 21 . napon mutatta a legmagasabb értéket $(3,55 \mathrm{ng} / \mathrm{ml})$, míg a felolvasztott minták esetében a maximumértéket $(1,95 \mathrm{ng} / \mathrm{ml})$ a tenyésztés 14 . napján mértük.

\section{Megbeszélés}

A petefészekszövet-fagyasztás egyre szélesebb körben kerül alkalmazásra daganatos betegek esetén a termé- 


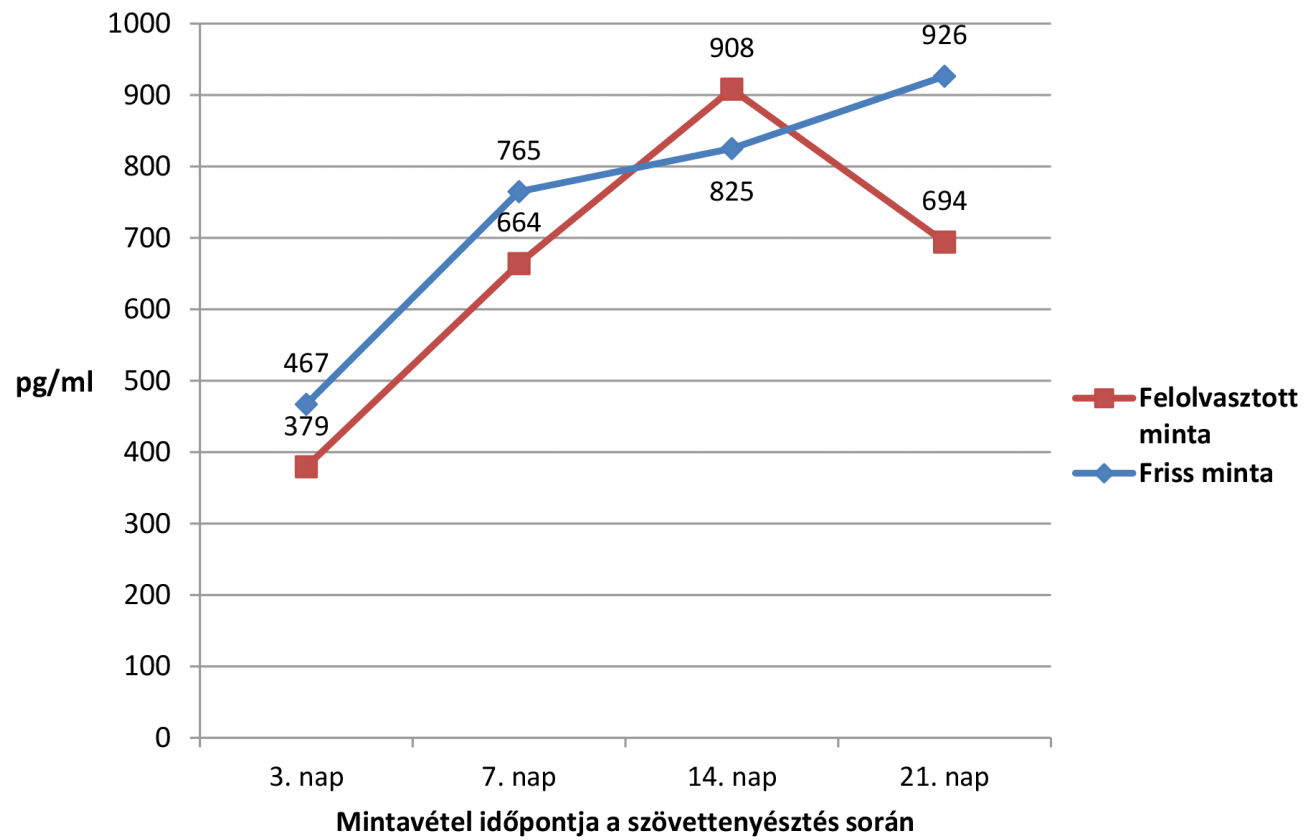

5. ábra

Friss és fagyasztott-felolvasztott szövetminták ösztradioltermelése 21 napos szövettenyésztés során. A feltüntetett értékek több szövetminta tenyésztése során kapott átlagértékek. Nincs szignifikáns különbség az azonos idôszakban mért hormonértékek között a friss és fagyasztott-felolvasztott szövetminták esetében

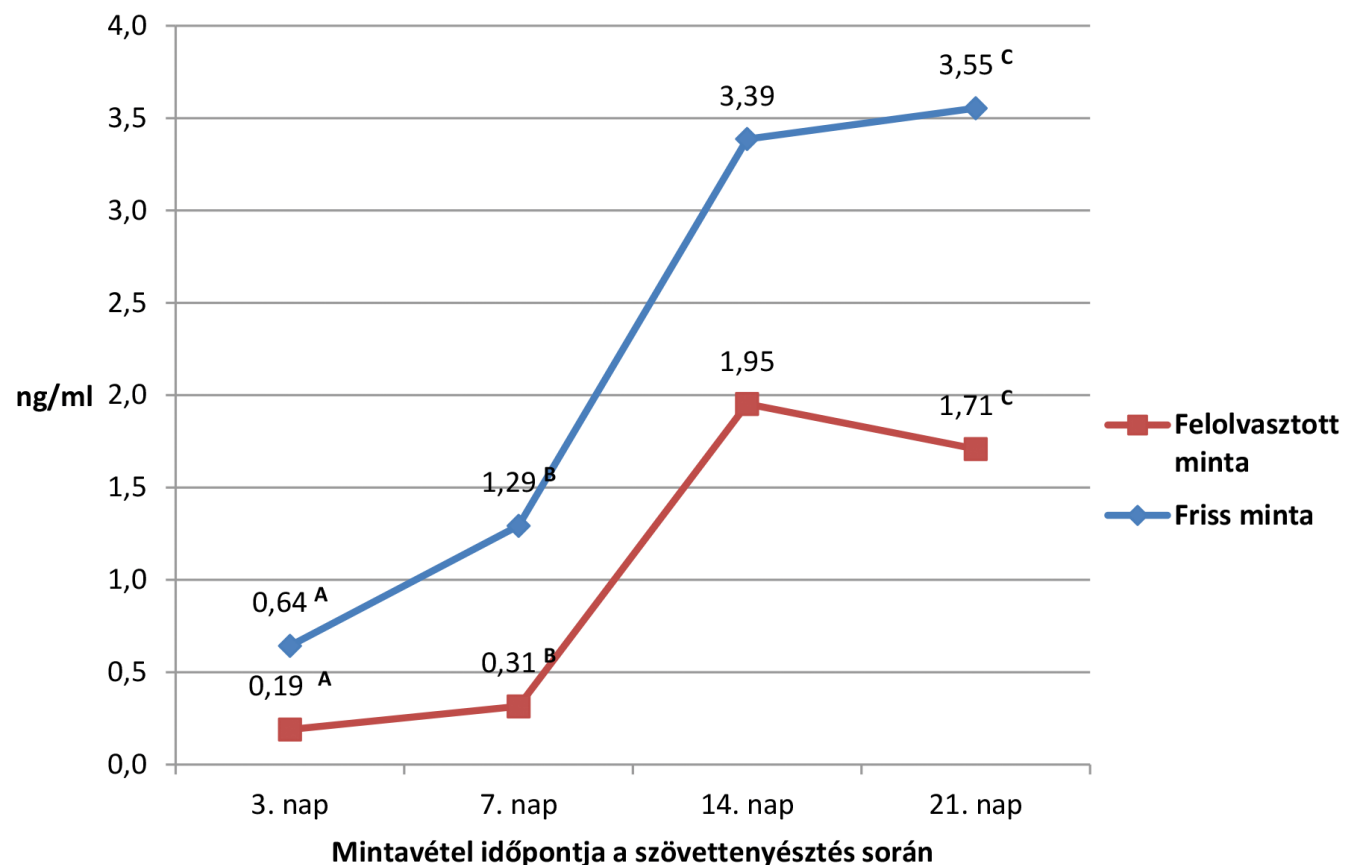

6. ábra

Friss és fagyasztott-felolvasztott szövetminták progeszterontermelése 21 napos szövettenyésztés során. A feltüntetett értékek több szövetminta tenyész tése során kapott átlagértékek. A friss és felolvasztott szövetminta progeszterontermelése között szignifikáns különbséget mértünk: A, B: p<0,01; $\mathrm{C}: \mathrm{p}=0,03$

kenység megörzése céljából [10, 13, 17, 18]. Fontosnak tartjuk ugyanakkor, hogy az új és folyamatos fejlesztés alatt álló módszerek rutin klinikai alkalmazásának bevezetése előtt azok hatékonyságát ellenőrizzük. Az itt bemutatott vizsgálatok elsődleges célja tehát az volt, hogy kutatásra felajánlott szövetmintákon igazoljuk, hogy az általunk alkalmazott fagyasztási és feldolgozási módsze- rek során megőrizhető a petefészekszövet-minták életképessége.

A fagyasztás-felolvasztás utáni szövetek életképességének vizsgálatára számos módszer áll rendelkezésre. A hagyományos fénymikroszkópos szövettani vizsgálatok mellett beszámoltak elektronmikroszkópos vizsgálatok [19, 20], valamint különböző vitális festések alkalmazá- 
sáról $[13,15,19,21]$ is. Ugyanakkor több szerző rámutatott arra, hogy a sejtszerkezeti és szövettani vizsgálatok önmagukban nem adnak elegendő információt a felolvasztott szövetek életképességéről. Ezért a túlélési vizsgálatok kiterjedtek a szöveti hormontermelés [13, 22], valamint a tüszőket alkotó sejtek apoptózisvizsgálatára is [23].

Vizsgálataink tervezésekor fontos szempont volt, hogy a petefészekszövet-minták túlélésének megítélésekor olyan módszereket válasszunk, amelyek a részt vevő intézetekben rutinszerúen elvégezhetők. Ezért a hagyományos szövettani vizsgálatok mellett Neutral Red vitális festést, valamint a szövetminták 21 napos tenyésztése során ösztradiol- és progeszteronméréseket végeztünk a szövettenyésztő tápoldatból.

A hagyományos szövettani vizsgálatok során minden mintából egy-egy metszet került értékelésre. A szövetmintákban a tüszők száma változó volt (0-76), és előfordultak olyan metszetek is, ahol egyáltalán nem találtunk tüszőket. Hasonló megfigyelést közöltek Bastings és $m$ tsai $[13]$ is, akik a tüszők alacsony számát vagy hiányát azzal magyarázzák, hogy kutatási célra csak kisméretü szövetminta állt rendelkezésre. Ezenkívül saját vizsgálatunkban a kutatási célra felajánlott szövetminták reproduktív betegségekben szenvedő, petefészekmütéten átesett betegektől származnak, akiknél az alapbetegség típusától és súlyosságától függően a petefészekszövet minősége és így a tüszők száma is súlyosan csökkenhetett.

A petefészekszövet-fagyasztás alkalmazásakor a legfontosabb kérdés az, hogy a felolvasztást követően menynyi életképes tüsző marad a szövetmintákban. A vizsgálatok módja, a normális vagy necroticus tüszók besorolása munkacsoportonként változik, így az eredmények sem teljesen összehasonlíthatók. Az irodalmi adatok áttekintéséből azonban egyértelmúen kitúnik, hogy a különböző fagyasztási módszerek eltérő mértékben ugyan, de csökkentik a normális morfológiájú tüszők számát a felolvasztott mintákban [23-25].

Az általunk elvégzett hagyományos szövettani vizsgálat alapján a friss mintában $15 \%$, míg a fagyasztott-felolvasztott mintában 38,2\% volt a necroticus tüszők aránya. Ez azt jelenti, hogy az általunk alkalmazott módszerek eredményeként $23,2 \%$-kal csökkent a normális vagy minimális elváltozásokat mutató tüszők gyakorisága. Eredményeinkhez hasonlóan más szerzők is a tüszők 50 $80 \%$-os fagyasztás utáni túléléséról számoltak be [14, 23], de van olyan közlemény, ahol a fagyasztás-felolvasztás eredményeként a tüszők több mint $60 \%$-a nekrotizálódott [25].

Saját eredményeink egyúttal arra is rámutatnak, hogy a szövetmintákban megfigyelhető tüszőknek a fagyasztást és felolvasztást, valamint a 21 napos szövettenyésztést követően több mint $25 \%$-a sértetlen vagy csak minimális elváltozást mutat.
Az általunk alkalmazott Neutral Red festés eredménye szintén igazolta az életképes sejtek, illetve tüszők jelenlétét a felolvasztás utáni szövetmintákban. Az eljárást más szerzők is alkalmasnak találták arra, hogy élő tüszők jelenlétét mutassák ki petefészekszövet-mintákban [15, 16]. A módszer egyik legfontosabb előnye, hogy egyszerü, gyors és nem igényel speciális technikai feltételeket (például fluoreszcens mikroszkóp), így bármelyik aszszisztált reprodukciós laboratórium rutinfelszerelésével elvégezhető. Hasonló módon, de Calcein AM-festéssel vizsgálták a szövetminták túlélését Bastings és mtsai [13], akik minden vizsgált mintában pontosan meghatározták az élő tüszők számát. Saját tapasztalataink azt mutatták, hogy a neutralred-festés alkalmazásával egyértelmúen elkülöníthetők az élő és elhalt sejtek, illetve sejtcsoportok. Ugyanakkor az enzimes emésztést követően a szövetmintából megmaradt szabályos, kerek alakú tüszők és az egyéb festődő, szabálytalanabb alakú sejtcsoportok között csak szubjektív módon lehet különbséget tenni. Ezért a neutralred-festést inkább csak a petefészekszövet sejtjeinek fagyasztás utáni túlélésének megítélésére, nem pedig a mintában lévő életképes tüszők pontos számának meghatározására tartjuk alkalmasnak.

A szöveti hormontermelés szintén jól mutatja a petefészekszövet-mintákban lévő tüszők túlélését. A szövettenyésztés során 14 napig folyamatosan növekvő hormontermelést figyeltünk meg a fagyasztott-felolvasztott szövetminták esetében, ami megegyezik az idevonatkozó szakirodalmi adatokkal $[13,22,26]$. Vélhetően a beavatkozás során károsodott tüszők múködésének kiesése miatt a felolvasztott szövetmintákban kevesebb életképes tüszőtől kisebb mennyiségű hormontermelés lenne elvárható. Ennek ellenére saját vizsgálatainkban a fagyasztott-felolvasztott szövetminták ösztradioltermelése nem tért el lényegesen a friss szövetmintákhoz képest, mindössze a hormontermelés maximuma tevődött korábbi időpontra. A fagyasztott-felolvasztott minták progeszterontermelése a friss mintákéhoz hasonló növekedést mutatott, de az egyes időpontokban mért értékek elmaradtak azoktól. Bastings és mtsai [13] a fagyasztás-felolvasztás hatására alacsonyabb ösztradioltermelést mutattak ki a szövettenyésztés 4 . napján, míg progeszterontermelés esetében a 7 . napon mértek alacsonyabb értéket.

\section{Következtetések}

A petefészekszövet-minták fagyasztására, tárolására és felolvasztására intézetünkben alkalmazott módszerekkel biztosítottuk a petefészekszövetben található tüszők hosszú távú túlélését. Vizsgálataink során nyert tapasztalataink és eredményeink alapján, érvényes kutatási engedély birtokában, intézetünkben megkezdtük a petefészekszövet-fagyasztás bevezetését a klinikai gyakorlatba daganatos betegek petefészekszövet-átültetése és termékenységének megőrzése céljából. 
Anyagi támogatás: A közlemény megírása, illetve a kapcsolódó kutatómunka anyagi támogatásban nem részesült.

Szerzôi munkamegosztás: F. P., B. A.: Kutatásvezető, kutatási terv kidolgozása és kivitelezése, adatok értékelése, közlemény összeállítása. U. J., R. J.: Kutatási terv kidolgozása, adatok értékelése, közlemény összeállítása. F. L.: Szövettani vizsgálatok végzése, adatok értékelése. S. A.: Szövettenyésztéssel kapcsolatos vizsgálatok kivitelezése, adatok értékelése, közlemény összeállítása. Cs. G.: Szövettenyésztéssel kapcsolatos vizsgálatok kivitelezése és az eredmények értékelése. L. Á., K. Z.: Eredmények értékelése, közlemény összeállítása.

Érdekeltségek: A szerzőknek jelen kutatómunkával kapcsolatban nincsenek érdekeltségeik.

\section{Irodalom}

[1] Donnez, J., Jadoul, P., Squifflet, J., et al.: Ovarian tissue cryopreservation and transplantation in cancer patients. Best Pract. Res. Clin. Obstet. Gynaecol., 2010, 24(1), 87-100.

[2] van der Kaaij, M. A., Heutte, N., Meijnders, P., et al.: Premature ovarian failure and fertility in long-term survivors of Hodgkin's lymphoma: a European Organisation for Research and Treatment of Cancer Lymphoma Group and Groupe d'Étude des Lymphomes de l'Adulte Cohort Study. J. Clin. Oncol., 2012, 30(3), 291-299.

[3] Smith, A. U., Parkes, A. S.: Preservation of ovarian tissue at low temperatures. Lancet, 1951, 258(6683), 570-572.

[4] Parrott, D. M.: The fertility of mice with orthotopic ovarian grafts derived from froozen tissue. J. Reprod. Fertil., 1960, 1, 230-241

[5] Gosden, R. G., Baird, D. T., Wade, J. C., et al.: Restoration of fertility to oophorectomized sheep by ovarian autografts stored at $-196{ }^{\circ} \mathrm{C}$. Hum. Reprod., 1994, 9(4), 597-603.

[6] Hovatta, O., Silye, R., Krausz, T., et al.: Cryopreservation of human ovarian tissue using dimethylsulphoxide and propanediolsucrose as cryoprotectants. Hum. Reprod., 1996, 11(6), 12681272 .

[7] Donnez, J., Dolmans, M. M., Demylle, D., et al.: Livebirth after orthotopic transplantation of cryopreserved ovarian tissue. Lancet, 2004, 364(9443), 1405-1410.

[8] Dolmans, M. M.: Ovarian transplantation. Hum. Reprod., 2014, 29(Suppl. 1), il8

[9] Donnez, J., Dolmans, M. M.: Ovarian cortex transplantation: 60 reported live births brings the success and worldwide expansion of the technique towards routine clinical practice. J. Assist. Reprod. Genet., 2015, 32(8), 1167-1170.

[10] Donnez, J., Dolmans, M. M., Pellicer, A., et al.: Restoration of ovarian activity and pregnancy after transplantation of cryopreserved ovarian tissue: a review of 60 cases of reimplantation. Fertil. Steril., 2013, 99(6), 1503-1513.
[11] Amorim, C. A., Curaba, M., Van Langendonckt, A., et al.: Vitrification as an alternative means of cryopreserving ovarian tissue. Reprod. Biomed. Online, 2011, 23(2), 160-186.

[12] Isachenko, V., Isachenko, E., Reinsberg, J., et al.: Cryopreservation of human ovarian tissue: comparison of rapid and conventional freezing. Cryobiology, 2007, 55(3), 261-268.

[13] Bastings, L., Liebenthron, J., Westphal, J. R., et al.: Efficacy of ovarian tissue cryopreservation in a major European center. J. Assist. Reprod. Genet., 2014, 31(8), 1003-1012.

[14] Zhou, X. H., Wu, Ү. J., Shi, J., et al.: Cryopreservation of human ovarian tissue: comparison of novel direct cover vitrification and conventional vitrification. Cryobiology, 2010, 60(2), 101-105.

[15] Chambers, E. L., Gosden, R. G., Yap, C., et al.: In situ identification of follicles in ovarian cortex as a tool for quantifying follicle density, viability and developmental potential in strategies to preserve female fertility. Hum. Reprod., 2010, 25(10), 2559-2568.

[16] Kristensen, S. G., Rasmussen, A., Byskov, A. G., et al.: Isolation of pre-antral follicles from human ovarian medulla tissue. Hum. Reprod., 2011, 26(1), 157-166.

[17] Rosendahl, M., Schmidt, K. T., Ernst, E., et al.: Cryopreservation of ovarian tissue for a decade in Denmark: a view of the technique. Reprod. Biomed. Online, 2011, 22(2), 162-171.

[18] Sánchez, M., Novella-Maestre, E., Teruel, J., et al.: The Valencia Programme for Fertility Preservation. Clin. Transl. Oncol., 2008, 10(7), 433-438.

[19] Hreinsson, J., Zhang, P., Swahn, M. L., et al.: Cryopreservation of follicles in human ovarian cortical tissue. Comparison of serum and human serum albumin in the cryoprotectant solutions. Hum. Reprod., 2003, 18(11), 2420-2428.

[20] Oktay, K., Newton, H., Gosden, R. G.: Transplantation of cryopreserved human ovarian tissue results in follicle growth initiation in SCID mice. Fertil. Steril., 2000, 73(3), 599-603.

[21] Sanfilippo S., Canis M., Ouchchane L., et al.: Viability assessment of fresh and frozen/thawed isolated human follicles: reliability of two methods (Trypan blue and Calcein AM/ethidium homodimer-1). J. Assist. Reprod. Genet., 2011, 28(12), 1151-1156.

[22] Huang, L., Mo, Y., Wang, W., et al.: Cryopreservation of human ovarian tissue by solid-surface vitrification. Eur. J. Obstet. Gynecol. Reprod. Biol., 2008, 139(2), 193-198.

[23] Xiao, Z., Wang, Y., Li, L., et al.: Needle immersed vitrification can lower the concentration of cryoprotectant in human ovarian tissue cryopreservation. Fertil. Steril., 2010, 94(6), 2323-2328.

[24] Oktem, O., Alper, E., Balaban, B., et al.: Vitrified human ovaries have fewer primordial follicles and produce less antimüllerian hormone than slow-frozen ovaries. Fertil. Steril., 2011, 95(8), 2661-2664.el.

[25] Marsella, T., Sena, P., Xella, S., et al.: Human ovarian tissue cryopreservation: effect of sucrose concentration on morphological features after thawing. Reprod. Biomed. Online, 2008, 16(2), 257-267.

[26] Sanfilippo, S., Canis, M., Romero, S., et al.: Quality and functionality of human ovarian tissue after cryopreservation using an original slow freezing procedure. J. Assist. Reprod. Genet., 2013, 30(1), 25-34.

(Fancsovits Péter dr., Budapest, Baross u. 27., 1088 e-mail: fancsovits.peter@noil.sote.hu) 